\title{
Particularity of informal Senegalese SMEs and Challenges of Their Formalization
}

\author{
Louis Sarr \\ Doctoral Student at the University of Thies-Senegal \\ Laboratory of Economic and Monetary Research (LAREM) \\ Dakar-Senegal
}

\begin{abstract}
In Senegal one of the major problems is the informal nature of the majority of SME. This article aims to show the specificity of Senegalese SMEs; the analysis of challenges faced in the formalization of the latter, their weight in the economy particularly on the Gross Domestic Product (GDP) and lastly, recommendations to overcome the noted problematics. It will also help correct figures that give a support that $99 \%$ of Businesses in Senegal are informal. The data come from the survey of the National Agency for Statistics and Demography (2019), descriptive methodology is used.
\end{abstract}

Keywords: SME, Formalization, GDP

\section{Résumé}

Les petites et moyennes entreprises (PME) sont considérées par plusieurs auteurs et par beaucoup de praticiens comme vecteurs de croissance et créatrices d'emplois. Elles sont selon les zones, organisées par les pouvoirs publics ou par les organismes internationaux. Cependant, elles restent confrontées à beaucoup de difficultés aussi bien dans la phase de création de développement que de déclin.

Ces problèmes sont de différents ordres et vont de la gestion, l'accès au foncier, l'accès aux services financiers et non financiers, à des problèmes liés l'environnement dans lequel elles évoluent. Au Sénégal, un des problèmes majeurs est le caractère informel de la grande majorité des PME. C'est l'objet de cet article qui a pour objectif de montrer la spécificité de ces PME sénégalaises face au défi de la formalisation, analyser leurs poids dans l'économie notamment sur le Produit Intérieur Brut (PIB) et faire des recommandations dans ce sens. Cela permettrait de corriger les chiffres qui donnent un taux de $99 \%$ d'entreprises informelles au Sénégal.

Les données proviennent de l'enquête de l'Agence Nationale de la Statistique et de la Démographie (2019) et nous avons utilisé une méthodologie descriptive.

Mots clés: PME, formalisation, PIB

\section{Introduction}

Long touted as "fragile with limited resources, very few development prospects and uncertain sustainability", Small and Medium-sized Enterprises (SMEs) are now recognized as active components and key players in the development, economic and social vitality of all regions (St-Pierre, Labelle, 2017). The challenge is therefore for States, and more particularly developing countries such as Senegal, to strengthen SMEs and improve their competitiveness. We know that small and medium-sized businesses, despite a certain slowdown in their creation in the past decade, continue to be the primary jobs provider, not only in general, but also in many regions in industrialized or developing countries (Julien, 2005).

However, it's important to note that not all SMEs, once created, generate a lot of jobs or revitalize the regions. On one hand, about half of new enterprises do not exceed five-years after their creation. They are absorbed by others or go bankrupt. On the other hand, among those that remain, most of them stay relatively small or create few new jobs relative to the number of employees they had when they started. (Julien, 2003)

The particularity of Senegalese SMEs is that they have a central place in the private and public sector but also among professionals and researchers. Their problems are various but most the most common are the quality of their management, unreliable financial information and general informality.

Formalizing Senegalese SMEs will remove major constraints and make a huge step towards eradicating the previously cited problems. The general census of private companies produced by the National Agency for Statistics and Demography (RGE, 2016) supplementing data of the National Survey on SMEs (ENPME, 2014) show that SMEs account for $99.8 \%$ of Senegalese Companies with 407,882 economic units identified. But the vast majority of these SMEs are informal (97.3\%). 
The Senegalese Government has proven its awareness to the reality by developing public policies pertaining to help SMEs and their development. the aim is to reduce barriers to formalization, improve skills and production capacities in order to optimize their performance in domestic markets and facilitate their access to international markets. Some strategies were also aimed at promoting the creation of commercial links between SMEs and large companies.

It must be said that the world's SME environment has evolved considerably in recent years with a better-organized and more dynamic private sector with a strongly state-backed business support system.

The importance and interest in entrepreneurship are more obvious today in a world marked by the Globalization of the economy. SMEs need the support of governments to develop their products in a constantly changing environment.

In Senegal, SMEs are already facing increasing competition from businesses in the sub-region, northern Africa and also from the many and various imported $\mathrm{g}$ that possess comparative advantages. Indeed, it is imperative to have adequate support and development policies for SMEs, which are in an open and highly competitive world. Senegal's entry into the African Continental Free Trade Area (FTACAF) is a perfect example.

Indeed, the SME environment has become more international with borders opened according to multilateral free-trade agreements. Constraints are nonetheless present with borders because of the need for protection and general security, as it is the case in the United States (Labelle, 2017).

Informality is an integral part of African societies. It is common to urban and rural areas. Motorists can buy new windshield wipers, a cellphone refill or an ironing board in traffic jams. In rural areas, motorists can shop at any crossing where food and other necessities can be found. This economy at first glancedisorganized, in fact meets specific rules. ${ }^{1}$

In sub-Saharan Africa, statistics estimate that the informal sector accounts for 55\% of GDP and $80 \%$ of employment, according to an AFDB report (2014). Yetby definition, these figures underestimate reality (ILO, 2015).

Globally, informal SMEs are the backbone of the economy accounting for nearly $60 \%$ of employment and $53 \%$ of added value. (Julien, 2017).

From this point of view SMEs which make up the vast majority of Senegalese companies constitute a lever to fight poverty, a factor of proven economic growth and a springboard to economic emergence. SMEs therefore have a major role to play in the structural transformation of the economy, axis 1 of the Plan Sénégal Émergent (PSE). The latter is the economic and social policy defined by government authorities to lead the country towards emergence by 2035 .

SMEs are however mainly characterized by limited competitiveness and economic performance due among other things to low profitability and difficulties in investment and modernization. A number of constraints hinder their perfect integration into multilateral trade.

Thus it remains interesting even legitimate to analyze the particularity of these informal SMEs and their weight in the Senegalese economy.

The main objective of this article is to analyze the characteristics of informal SMEs and their importance in the Senegalese economy. More specifically, the aim is to highlight the particularity of informal Senegalese SMEs and to analyze their impact and participation on the country's GDP.

To analyze the weight of these informal SMEs in the Senegalese economy, we will compare them with formal SMEs by making a descriptive and comparative analysis.

The analysis will be based on the results of the study by the Agency for the Development and Supervision of Small and Medium Enterprises (ADEPME), in collaboration with the ANSD on the contribution of SMEs to GDP and employment. The remainder of the article is divided into five sections. The second section is a review of the theoretical and empirical literature. The third section proposes a characterization of SMEs. The fourth section explains the methodology adopted. The fifth section presents the results and their interpretation. The sixth and final sections conclude by highlighting the implications of economic policy.

\section{Theoretical and empirical literature review}

SMEs are regarded worldwide as providers of wealth and employment, regardless of their formal or informal status. In reality, it is a relatively small number of new and expanding small businesses that create a significant share of new jobs (Storrey and Johnson 1987).

\footnotetext{
${ }^{1}$ Study of the impact of SMEs on GDP and employment ANSD, ADEPME, 2019
} 
It is important to note that SMEs constitute a heterogeneous group (Eng. 1992, Lavigne and St-Pierre, 2002), but they are not large companies in miniature (Lavigne and St-Pierre, 2002). This taxonomy of SMEs is indeed important for the efficient articulation of actions in their favor. Considering some SMEs as large companies in a reduced version may lead to inadequate considerations of their needs.

In short, knowledge is polarized: large companies are seen as models of success and exemplary management; while SMEs are smaller players with low yield prospects. This view of SMEs also contributes to making it difficult to recruit specialized staff. The need for recruiting qualified staff however becomes more pressing as the traditional based economy moves towards the knowledge-based economy (Labelle, 2017).

Such diversity mentions upper for this type of company brings us to certify that there are not SME but there are SMEs (Torres 1999). In fact, SMEs are created related to factors corresponding to their geographical area, as regional potentialities to economic and environmental activity.

It is important to note however the central role of the entrepreneur into the development of the SME. The idea of a project comes from them that can be done as in fast track or gradually (Julien 2017). That confirms the idea of <willing> by SERRES (1605).

With SMEs, management is generally very much concentrated often at the owner's level. (Colot et Croquet, 2007; Van Caillie, 1998).They are generally confused with the business and represents the strategic person, so that, without him, things can go wrong in the firm (Boissin, et al, 2009; Olekalo, 2011).

These relationships between the idea and the type of organization that follows explain why researchers attach so much importance to entrepreneurs in the creation and development of SMEs. We even talk about individualization of small business while the entrepreneur marks its development and therefore the type of management and, ultimately, the vision and thus the broad orientations that he makes for it (Julien, 2017). Hamidou (1994), working on the determinants of the financial diagnosis of SMEs, explained how this variety also questioned enormous difficulties both in the definition of SMEs and in their study. We note that the definition of SME is not universal (Pacito, 2006; Torrès, 1999). This varies according to economic zones, institutions, countries and legislation (OECD, 2004). Pierre André Julien, founder in 1988 with Michel Marchesnay of the «Revue Internationale PME», the first French-language journal, always provides a relevant description of the specificities of SMEs (leadership role, low task specialization, informal and reactive strategy, direct and simple information systems, direct contact with the client (Messeghem, 2017).

In their book "Les entreprises informelles de l'Afrique de l'Ouest francophone" (Benjamin and Ndiaye, 2012), use the ILO definition (OIT, 2002), which defines informal company as not registered company, whose owner is an individual or a household whose assets are not severable from those of the firm, and for which there is no reliable accounting to trace operations. It is clear that only family businesses, housed in the institutional sector of households according to the United Nations accounting system (SNA, 1993), meet this definition criterion.

But it's also important to note that other criteria, such as keeping regular accounts and registering the entity in question, also come into play in this definition. According to the Commission, the informal sector is made up of small enterprises employing less than 10 people and which are not registered with a given administration.

The following six criteria are used: size, registration, keeping of sincere accounts, fixed location then access to credit, and non-payment of taxes and type of paid taxes (Benjamin \&Ndiaye, 2012).

However, this definition has its limit because access to credit is, in our view, a result in some cases of formalization. These authors, based on the Khi-deux independence test, finally chose only three criteria, which are: the size of the enterprise, the tax regime to which it is subject and the maintenance of an honest accounting.

The National Institute of Statistics and Economic Studies (INSEE) ${ }^{3}$ of France defines the SME according to three criteria: the number of employees, the turnover and the balance sheet total. According to this institution, SMEs are companies whose number of employees does not exceed 250 and the annual turnover is less than 50million of Euros or whose balance sheet total does not exceed 43million of Euros (Hamidou, 2014)

According to ANSD (2016), are considered informal SMEs the ones not registered in the Trade and Real Estate Credit Registry, that do not hold accounts according to the West African Accounting System (SYSCOA)

\footnotetext{
${ }^{2}$ Mahamadou D. Hamidou MEMORY on the determinants of the financial diagnosis of Smes (1994),

${ }^{3}$ Implementing Decree (No. 2008-1354) of Article 51 of the Law on the Modernization of the Economy, relating to the criteria for determining the class of membership of an enterprise for the purposes of statistical and economic analysis
} 
The authors consider that bookkeeping is the recording of all the company's accounting records according to the standards of a chart of accounts. One of its objectives is to meet the legal obligations of the tax authorities: VAT, income declaration and social funds.

As in the other WAEMU countries, SYSCOA is the accounting system used in Senegal since January 1st 1998. On January 1st 2001, the OHADA Uniform Act on Accounting was adopted. This aims to harmonies the accounting rules relevant into countries member of OHADA due to the established framework, the OHADA Accounting System (abbreviated to SYSCOHADA).

In the RGE, three accounting systems have been defined: SYSCOA, the harmonized accounting system other than SYSCOA (Banking Accounting Plan (PCB), Accounting Framework for Decentralized Financial Systems (RC-SFD) and the Inter-African Conference on Insurance Markets (CIMA) code and non-formal accounting, that is, the use of account book. Thus, $15.2 \%$ of economic units hold written accounts. Of these, $80.3 \%$ use account book, so an informal accounting system. Those using SYSCOA account for $18.4 \%$ and the rest use other harmonized accounting systems.

\section{Characterization of SMEs}

In Africa, definitions vary from country to country but remain characterized by the number of employees and size. In developed countries, the criteria used for the definition of SMEs are different from those used above. Nevertheless, the most common criterion is still the number of employees although this may well exceed that used in developing countries.

Despite all that is in the definition of SME, we can classify SMEs into two major groups. These are SMEs operating in compliance with regulations and those operating in the informal sector.

In Senegal, the definition of a SME is regulated by the Economic Modernization Act. Small and Medium-Sized Enterprise (SME) means any autonomous natural or legal person, a trader or producer of market goods and/or services, and whose turnover excluding annual taxes does not exceed two billion $(2,000,000,000)$ CFA francs; any SME of which more than $25 \%$ of its share capital is directly held by a private or public company, other than venture capital companies and institutional investors, ceases to be autonomous within the meaning of this law.

The SME are composed by Entrepreneurs, very small enterprise, Small Enterprise and Medium Enterprise defined below. The business must be legally reported and must keep regular records. The Entrepreneur: any natural person carrying out, individually, a professional, civil, commercial, craft, agricultural or service activity, whose annual turnover excluding taxes does not exceed:

30,000,000 FCFA for commercial activities; 20,000,000 FCFA for craft and related activities; 10,000,000 CFA for the provision of services.

Very Small Enterprise (SBT): any person, other than a physical or legal entrepreneur, engaged in a professional, civil, commercial, craft, agricultural, industrial or service activity, With an annual turnover of less than or equal to 100,000,000 FCFA. The Very Small Enterprise maintains, at least, a lean accounting system;

Small Enterprise (PE): any natural or legal person carrying on a professional, civil, commercial, craft, agricultural, industrial or service activity, whose annual revenue excluding taxes is greater than 100,000,000 FCFA and less than or equal to 500,000,000 FCFA. It maintains accounts either internally, by a Chartered Accountant or by an Approved Management Centre (CGA) or any other similar approved structure;

Medium Enterprise (ME): any natural or legal person carrying on a professional, civil, commercial, craft, agricultural, industrial or service activity, with annual revenue excluding taxes of more than 500,000,000 FCFA and less than or equal to 2,000,000 FCFA. It maintains accounts according to the normal system and certified by a Chartered Accountant;

Half of the world's population is known to work and produce in the informal economy (Formalization Workshop Report, ILO 2015). According to this study, in sub-Saharan Africa, informal employment accounts for $65 \%$ of nonagricultural employment, $82 \%$ in South Asia and 47\% in Latin America. 91\% of SMEs in the world are in the informal economy. It receives special attention from authors and supports structures for SMEs, in order to facilitate the relationship between SMEs and financial structures.

Since $97.3 \%$ of Senegalese SMEs do not keep accounts in the SYSCOHA sense (ANSD, 2016), the consequences on their relationship with the financial sector can be negative. 
These problems related to information asymmetry underpin the "principle of the principal agent", which is the core of the agency's theory ${ }^{4}$, one of the theories of the industrial economy. It refers to a set of problems encountered when the action of an economic actor, designated as the "principal", depends on the action or nature of another actor, the "agent", on which the principal is imperfectly informed. This is how the great majority of Senegalese SMEs still face this problem in accessing formal sector financial services.

Indeed, any agency relationship often results in an asymmetry of information between individuals because, on the one hand, officers generally know more about the task at hand than the principal and, on the other hand, it is often difficult and expensive for the principal to "measure the efforts made by an agent in fulfilling their obligations and consequently, to specify by contract, what these must be" (Charreaux et al. 1987, p.25) ${ }^{5}$ It is therefore a question of studying the consequences of asymmetry of information. The graph below from the Central Bank (BCEAO) report (2017) shows the main causes of the difficulties of Senegalese SMEs. One of the difficulties remains low quality information.

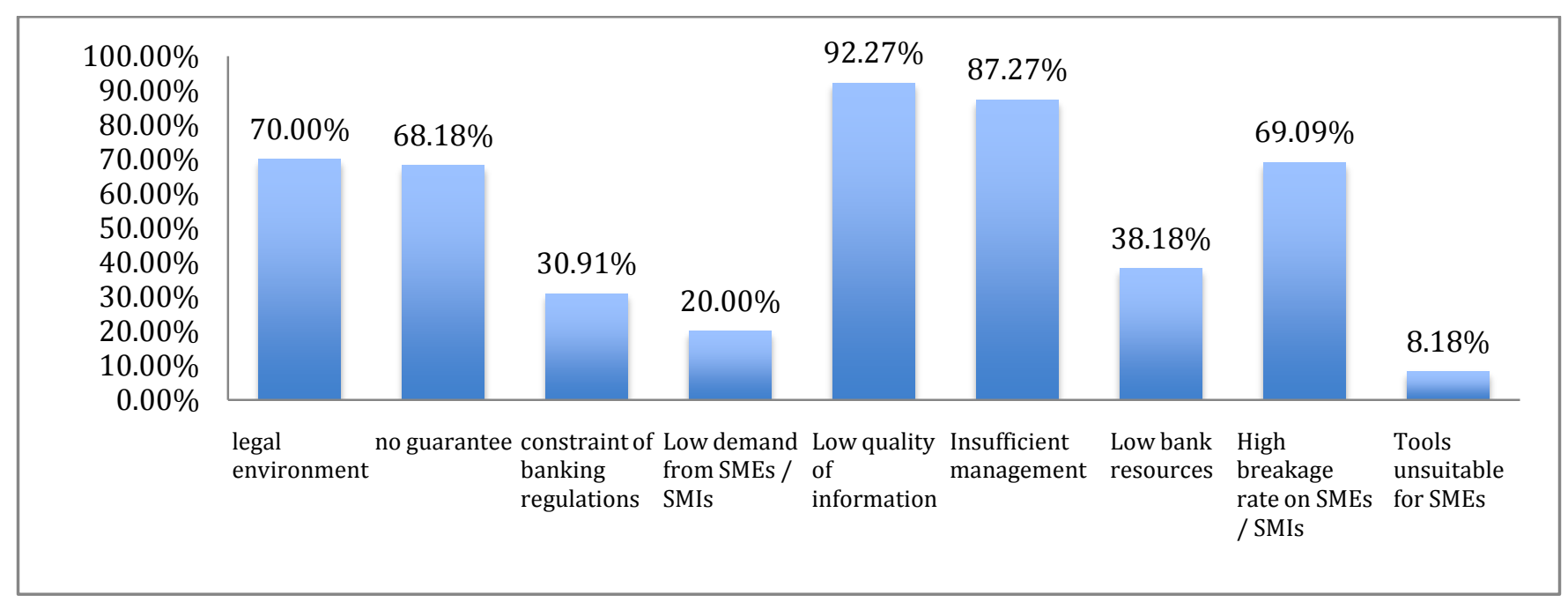

\section{Methodology}

Within the framework of this Article, any natural or legal person exercising a professional, civil, commercial, craft, agricultural, industrial or service activity shall be considered as a formal SME, whose annual turnover excluding taxes is less than 2,000,000,000 FCFA. It shall maintain accounts in accordance with the normal system of SYSCOA, certified by a Chartered Accountant or other harmonized system. It must also have a NINEA or a trade register Using data from the Economic and Financial Data Bank (BDEF), the General Census of Enterprises (RGE) and the National Survey of Informal Production Units in Senegal (ENUPIS), identified and ranked SMEs.

For the characterization of SMEs, results of the main surveys carried out in recent years have been used. This is mainly the General Business Census (RGE) conducted in 2016 and the National SME Survey (ENPME) conducted in 2013.

The methodological approach adopted by the authors of the study is the "production" approach used in Senegal to calculate GDP. Indeed, the wealth created by SMEs is the sum of the value added (PV). It is obtained by differentiating between Production $(\mathrm{X})$ and intermediate consumption $(\mathrm{Ci}) . \mathrm{VA}=\mathrm{X}-\mathrm{Ci}$.

According to the results of the study, gross value added is defined as the value of output minus intermediate consumption. It represents the contribution of labor and capital to the production process and is of interest for analysis because when the value of taxes on products (less subsidies on products) is added, the sum of the value added of all resident units gives the GDP.

The data obtained were analyzed using descriptive statistics.

\footnotetext{
${ }^{4}$ Michael C. Jensen and William H. Meckling, "Theory of the firm: Managerial behavior, agency costs and ownership structure," Journal of Financial Economics, vol. 3, no 4, October 1976, p. 308

${ }^{5}$ Charreaux G., Couret A., Joffre P., Koenig G. et de Montmorillon B. (1987), "De nouvelles théories pour gérer

l'entreprise", Paris, Economica
} 


\section{Presentation and interpretation of results}

Between 2014 and 2016, Senegal's SMEs recorded an overall gross value added of CFAF 3,465 billion to CFAF 4019 billion, an increase of $16 \%$ while GDP rose from CFAF 9775 billion to CFAF 11,251 billion, an average contribution of $35 \%$ over these three years, with an amount of CFAF 3,828 billion.

However, this contribution is mainly made by informal SMEs. Taken separately, the informal sector contributes an average of $30.2 \%$ of GDP, while the formal sector contributes an average of $5.6 \%$ overthree years, as shown in these graphs.

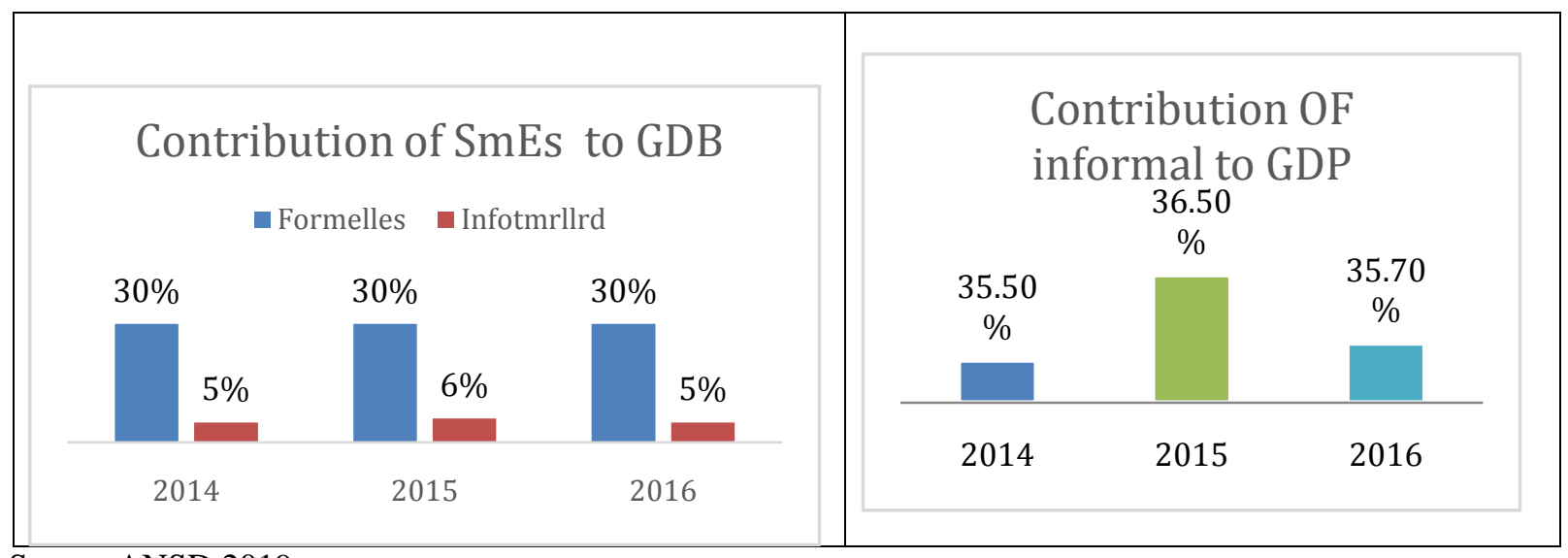

Source:ANSD,2019

\section{Overall distribution to GDP}

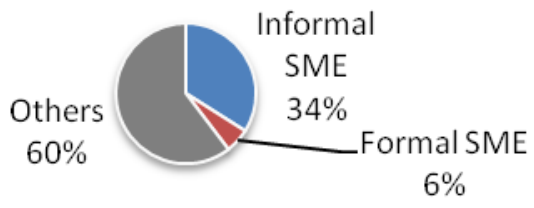

Source: ANSD 2019

Leadership is also an indispensable asset in this category. Indeed, according to the survey, people currently running them have created the vast majority of informal production units. Barely $5 \%$ of the heads of UPI have inherited them when a family patrimony is transferred, and in $1.4 \%$ of the cases it is a transfer of an already existing unit, created outside the family circle. In addition, informal production units are monocephalic, the share of the multiple establishment enterprises being very low (3.6\%). The dynamics of the informal sector are more a dynamic of job creation/generation than a real enterprise dynamic.

Contrary to popular belief, self-employment in the informal sector is generally claimed. Thus, about one third (32.0\%) of heads of production units consider the informal sector to be a preferred mode for being independent and $29.9 \%$ think it is the best way to enter the employment market. $22.3 \%$ support the possibility of obtaining a better income than the wage they might otherwise be entitled to.

\section{Conclusion}

The study on the particularity of informal Senegalese SMEs was carried out using the various existing data available at the level of the National Agency for Statistics and Demography between 2014 and 2016, including EGR, BDEF, revamped national accounts data and external trade data.

It should be remembered that these so-called "informal" companies are at least registered in the Trade Registry and have a National Business and Association Identification Number (NINEA). However, the lack of record keeping makes it difficult for them to keep track of their activities, as data on their activities requires a binding collection work

The weight of informal SMEs in the economy is indisputable because they not only constitute the vast majority but also because of their presence in virtually all sectors of activity. For example, in important sectors such as livestock farming and fisheries, informal SMEs account for $99.61 \%$ and $79.72 \%$ of the total PV of SMEs in Senegal. 
In comparison with formal enterprises, we note that informal SMEs contribute up to $30 \%$ of the GDP on average over the three years compared to $5 \%$ for formal SMEs. These results imply that the Government takes specific decisions to promoting a conducive environment to the formalization of informal SMEs.

In order to evolve and foresee the possibility of formalizing their activities, actors in the informal sector need appropriate support. It is also necessary to equip them with flexible tools capable of supporting their development without distorting or burdening their activities.

The formalization of Senegalese SMEs must be the political a priority for government authorities in view of the high rate they account for (97.3\%) according to the RGE 2016.

It is therefore imperative to put in place an incentive scheme such as the SME's special status to encourage SMEs to formalization in order to increase their competitiveness and potentially gain comparative advantages. This is a major challenge that must be met in order to go towards the emergence of Senegal. Without incentives such as better access to basic financial and social services, access to land, advantageous fiscal and social policies, the question may arise "what else is there to be formalized if the SME does not have special benefits".

Formalization is in fact a voluntary act of the SME manager that allows them to better manage their business and participate in the country's economy.

The fact of recognizing SMEs as major providers of wealth and jobs fully justifies the need to work for the implementation of real actions for the formalization of enterprises.

This is one of the major challenges sub-Saharan Africa and Senegal in particular face.

For Storey and Johnson (1987), the lesson to be drawn from such examples is that it does not appear that the number of small enterprises (quantity) determines the performance of the economy, but rather the quality of the enterprises. As a result, Storey and Johnson advocate, rather than a public policy focused on increasing the quantity of small businesses, a more selective public policy focused on fewer businesses, the best performing companies, which have a real capacity to improve the general economic situation.

Another challenge for Senegalese SMEs is to have national champions who will pull the economy (Storrey 1,987 ).

\section{Bibliography}

Ang, J. S. (1992). On the theory of finance for private heId firms.Journal of Small Business Finance, 1(3), 185-203.

Boissin, 1-P., Chalus-Sauvannet, M.-C., Deschamps, B., \& Geindre, S. (2009). Profils de chercheurs primoentrepreneurs et stratégies de croissance de la jeune entreprise innovante. Revue internationale PME : Économie et gestion de la petite et moyenne entreprise, 22(2), 41-65.

Colot, O., \& Croquet, M. (2007). La contribution de variables propres aux PME et à leur dirigeant dans l'explication de la structure financière des PME. La Revue des Sciences de Gestion (6),61-72.

Charreaux G., Couret A., Joffre P., Koenig G. et de Montmorillon B. (1987), "De nouvelles théories pour gérer l'entreprise", Paris, Economica.

Hamidou, 1994 Les facteurs déterminants du diagnostic financier des PME 1994

Julien, Entrepreneuriat régional et économie de la connaissance : une métaphore des romans policiers (Presses de l’Université du Québec, 2005)

Lavigne, B., \& St-Pierre, J. (2002). Association entre le système d'information comptable des PME et leur performance financière. 6ème congrès international francophone sur la PME.

OCDE (2002), Les PME à forte croissance et l'emploi, rapport de recherche, $149 \mathrm{p}$

OIT (2015) Rapport sur l'atelier sur la formalisation

Messeghem, Torres, (2015) Les grands auteurs en Entrepreneuriat et PME

Olekalo, R. (2011). Analyse du profil des dirigeants des pme à Brazzaville : cas des entreprises de service. Revue Congolaise de Gestion (1), 9-30.

Pacitto, 1-C (2006). L'internationalisation des PME : une tentative d'état des lieux. CIFEPME, Fribourg, Suisse, 25-27.

St Pierre. Labelle, Les PME d'hier à demain Bilan et perspectives, 2017

Torrès, O. (1999). Les PME : Flammarion Paris.

« De Serres, O. (1605), Théâtre d'agriculture \&mesnage des champs, 3e éd. revue et corrigée, chez A. Sangrain, Paris. (http://gallica.bnf.fr/ark:/12148/bpt6k 52175n »

Storey, D.J. et Johnson, S. (1987), Job Génération and Labour Market Change, Basingstoke, Hants : Macmillan »

Vann Caillie, D. (1998). Étude longitudinale de la structure financière des Petites ou Moyennes Entreprises belges issues de 9 secteurs industriels. Congrès International Francophone de la PME, Metz, 1-21. 


\section{7. $\quad$ Schedules}

Annex 1: SMEs contribution to employment by industry

\begin{tabular}{|l|l|}
\hline Activities sector & SME \\
\hline Agriculture, livestock, fishing & $90,42 \%$ \\
\hline Food Industries & $56,57 \%$ \\
\hline Textiles Industries & $97,91 \%$ \\
\hline Other Industries & $61,56 \%$ \\
\hline Buildings and Works & $24,38 \%$ \\
\hline Trade & $93,95 \%$ \\
\hline Transport and Telecom & $36,57 \%$ \\
\hline Hotel, Bar and Restaurant & $87,77 \%$ \\
\hline Business Services & $73,01 \%$ \\
\hline Personal Services & \\
\hline SMEs & $88,00 \%$ \\
\hline Large Companies & $\mathbf{8 0 , 4 6 \%}$ \\
\hline Total & $\mathbf{1 9 , 5 4 \%}$ \\
\hline
\end{tabular}

Annex 2: SME value added by industry

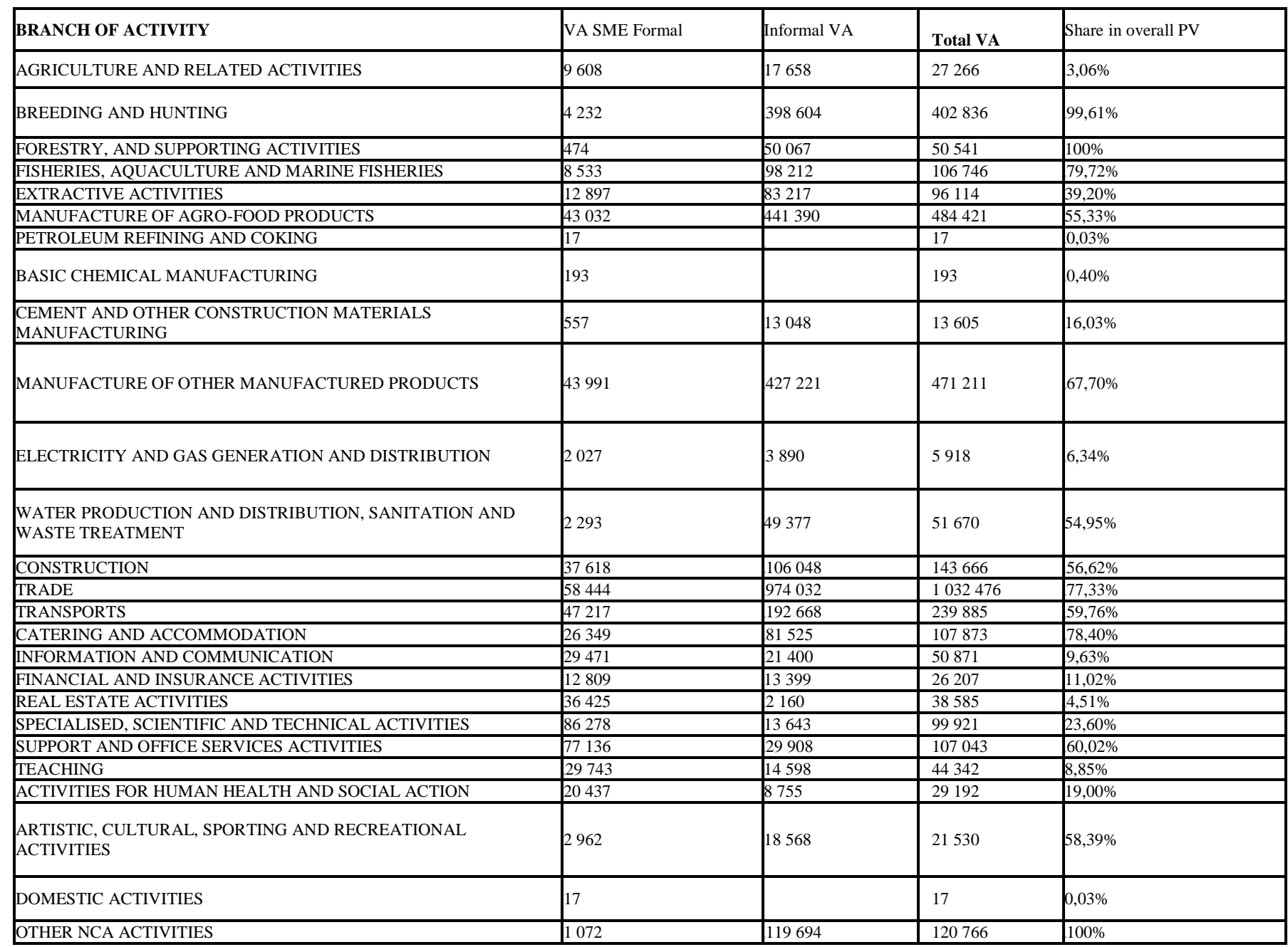

